Maзур H. О. ${ }^{[1 ; ~ O R C I D ~ I D: ~ 0000-0001-8673-5873], ~}$ к.е.н., доцент,

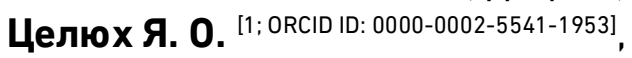
здобувач вищої освіти першого (бакалаврського) рівня

${ }^{1}$ Національний університет водного господарства та природокористування, м. Рівне

\title{
ТЕНДЕНЦІї ТА МОТИВИ РОЗВИТКУ ВОЛОНТЕРСТВА В УКРАЇНІ
}

На основі власного соціологічного дослідження виявлено основні тенденції ставлення населення України до волонтерства. Визначено актуальність різних видів волонтерської діяльності для сучасного українського суспільства. Досліджено рівень прихильності учасників опитування до кожного з напрямів доброчинності. Ідентифіковано мотиви та стримуючі фактори залучення громадян до волонтерської роботи.

Ключові слова: волонтерство; волонтерська діяльність; мотиви до волонтерської роботи; сфери волонтерської діяльності; соціологічне дослідження.

У наш час багато людей постійно долучаються до різноманітних суспільно корисних акцій та проектів у ролі добровольців. При цьому напрями волонтерської діяльності постійно розвиваються, чутливо реагуючи на нагальні потреби суспільства. Особливо чітко пріоритети волонтерської діяльності виокреслюються у кризові періоди розвитку держав 3 характерною для них соціальною, політичною та економічною нестабільністю. Основним ресурсом реалізації багатьох соціальних програм $€$ саме населення, що зумовлює актуальність дослідження можливостей залучення громадян до даного виду суспільно корисної діяльності.

Дослідженню особливостей генезису волонтерської діяльності у економічно розвинених країнах та окремим моментам практичної реалізації цього виду суспільно корисної активності приділено увагу в працях таких вітчизняних науковців і практиків, як А. Аніщенко, К. Василенко, Р. Ілейжер, А. Капська, Г. Крапівіна, Г. Лактіонова, Т. Лях, І. Пінчук та ін. Однак, майже відсутні системні дослідження реальної обізнаності різних категорій населення щодо особливостей волонтерської діяльності та мотивів, які спонукають громадян до даного виду доброчинності.

Тому постає завдання моніторингу настроїв суспільства щодо особливостей розвитку волонтерської діяльності в нашій державі, у т.ч. основних мотивів, які спонукають людей до благодійництва. 
Виявити основні тенденції ставлення громадян до волонтерства найдоцільніше на основі соціологічного опитування різних страт населення шляхом анкетування.

3 метою дослідження тенденцій щодо поінформованості мешканців України про особливості волонтерської діяльності, виявлення ключових настроїв населення щодо реалізації та розвитку різних сфер волонтерської діяльності та актуальних методів стимулювання до цього виду суспільної активності нами розроблена анкета 3 відповідним переліком питань. 3 допомогою google-форм опитано 105 респондентів, з яких 68,6\% становили жінки та 31,4\% чоловіки. Найбільшу частку респондентів (52,4\%) складає молодь у віці 18-24 роки. До опитування залучено представників різних сфер зайнятості: учні - 14 осіб (13,3\%), студенти денної форми навчання 49 осіб $(46,7 \%)$, студенти заочної (дистанційної) форми навчання 3 особи (2,9\%), наймані працівники - 32 особи (30,4\%), підприємці 4 особи (3,8\%), домогосподарки - 3 особи (2,9\%). Громадяни, які погодилися заповнити анкету, оцінюють свій рівень життя переважно як середній - 70 осіб, вище середнього - 24 особи, нижче середнього - 11 осіб. Нам вдалося опитати мешканців різних регіонів України, серед яких найбільше виявилося представників Рівненської, Волинської та Донецької областей.

Загальні результати дослідження свідчать, що всі респонденти знайомі з поняття «волонтерська діяльність» й частина з них брали безпосередню участь у різних волонтерських проектах (рис. 1).

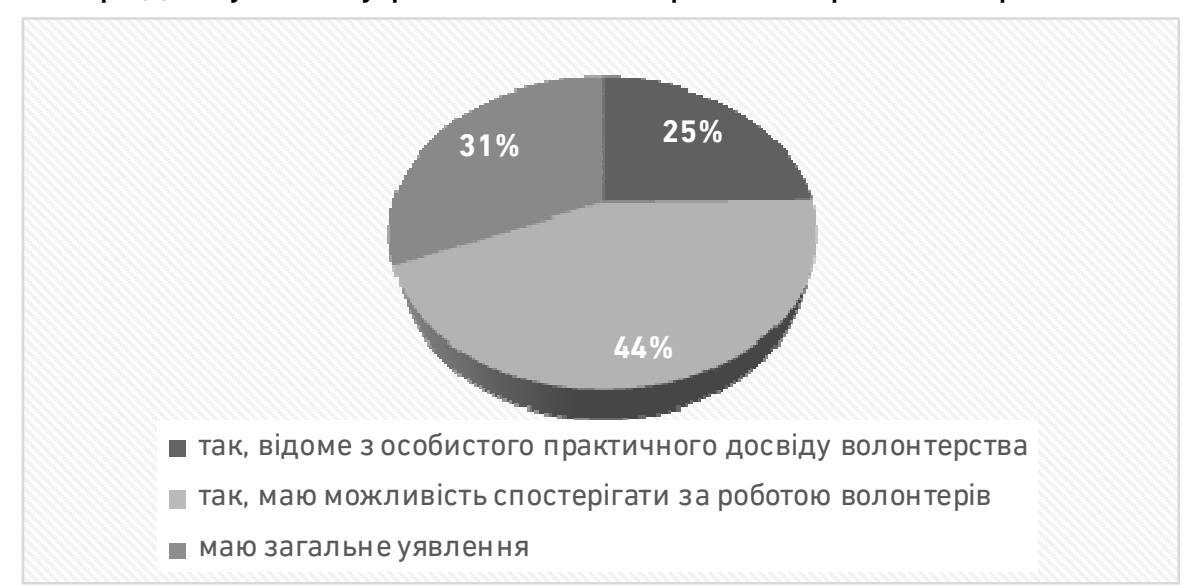

Рис. 1. Чи відоме Вам поняття «волонтерська діяльність»?

Те, що жоден з учасників опитування не обрав відповіді «ні, вперше чую про таку активність» або «ніколи не цікавив зміст цього поняття» свідчить про обізнаність наших громадян та небайдужість до соціальних процесів, які відбуваються у суспільстві. 
Однією з цілей опитування було визначення позиції населення щодо волонтерства як суспільного явища. В результаті аналізу відповідей респондентів встановлено, що $80 \%$ опитаних позитивно ставляться до такого виду суспільної активності, як волонтерство. Жоден респондент не задекларував негативного ставлення до активності добровольців і лише одна особа висловила свою байдужість до цього виду благодійництва (рис. 2).

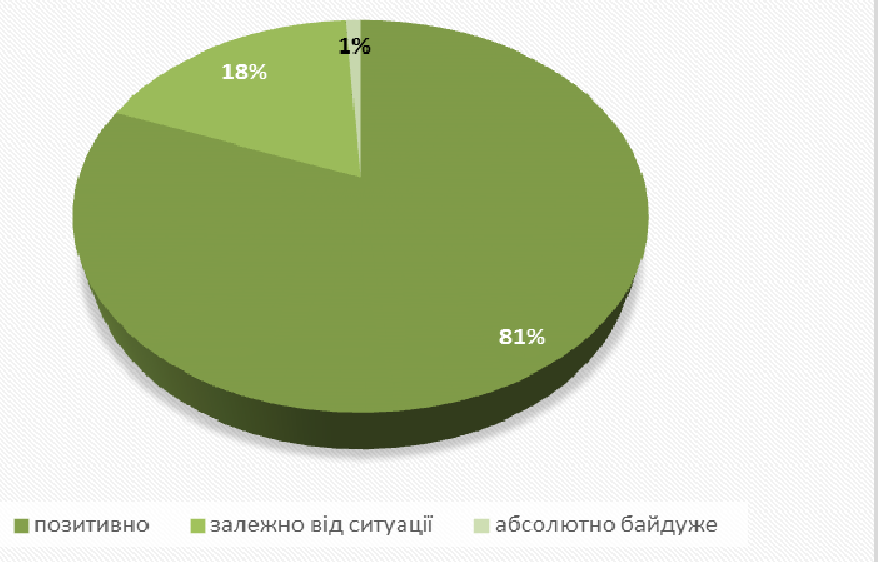

Рис. 2. Як Ви ставитесь до волонтерства як суспільного явища?

Враховуючи те, що значна кількість респондентів вважають волонтерство позитивним суспільним явищем, важливо також ідентифікувати рівень довіри українців до заходів, які реалізують волонтерські організації (рис. 3).

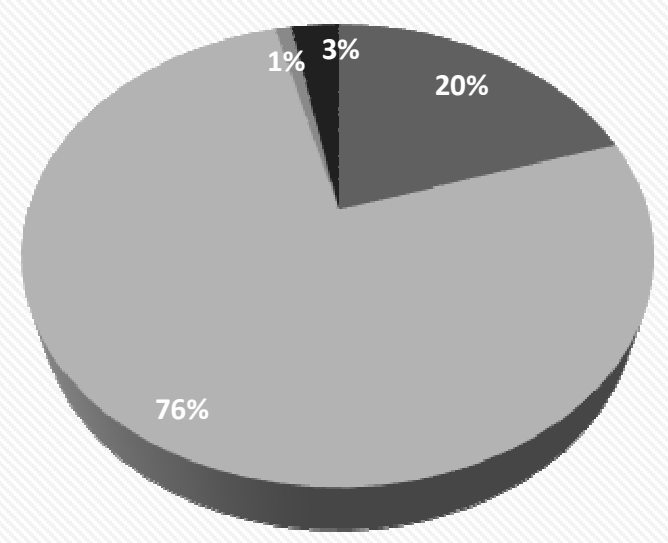

Рис. 3. Чи довіряєте Ви акціям, які проводяться волонтерами?

Беззаперечно довіряють українським волонтерам та акціям, які вони організовують, $20 \%$ респондентів. Значна частина громадян обережно ставляться до подібних заходів та проєктів. 76,2\% респондентів довіряють добровольцям лише в окремих ситуаціях, що 
швидше за все викликано випадками негідної поведінки фіктивних волонтерів, які імітують цей вид благодійництва з користолюбними намірами, створюючи таким чином у населення негативне сприйняття цього виду суспільної активності.

Більше половини респондентів мають досвід волонтерської роботи, а 11,4\% опитаних активно займаються нею зараз, що свідчить про активну громадську позицію українців та небайдужість до долі суспільства, в якому вони живуть (рис. 4).

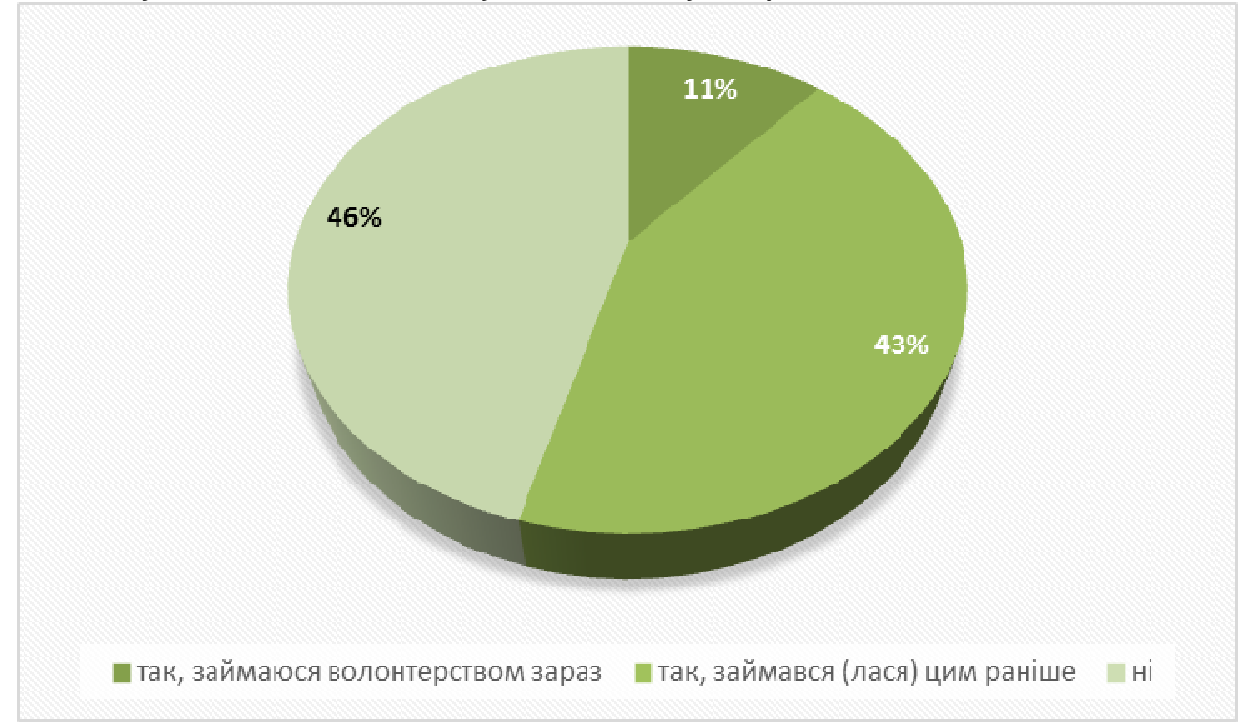

Рис. 4. Чи брали Ви участь у волонтерській діяльності?

Оскільки 45,7\% учасників опитування ніколи не брали участь у волонтерських заходах, доречно з'ясувати, що може перешкоджати людям долучатися до доброчинності.

За результатами соціологічного дослідження найвагомішим стримуючим фактором є байдужість до проблем оточуючих: 59\% опитаних вважають, що саме це уповільнює розвиток волонтерського руху в Україні. Суттєвою причиною низького рівня залучення населення до волонтерських проектів (зазначили 47,6\% опитаних) виявилася також недостатність інформації про акції, події та волонтерські організації, які їх влаштовують (рис. 5).

Оскільки, підпорядковуючись швидкому темпу сучасного життя, люди не завжди можуть знаходити можливість для добровільного служіння соціуму, такий фактор, як нестача часу займає третю позицію (вказали 44,8\% опитаних) в рейтингу перешкод до активної волонтерської діяльності. Матеріальна винагорода, на думку респондентів, також $є$ суттєвим стимулом до волонтерства. П̈ї відсутність вважають перепоною 31,4\% респондентів. 


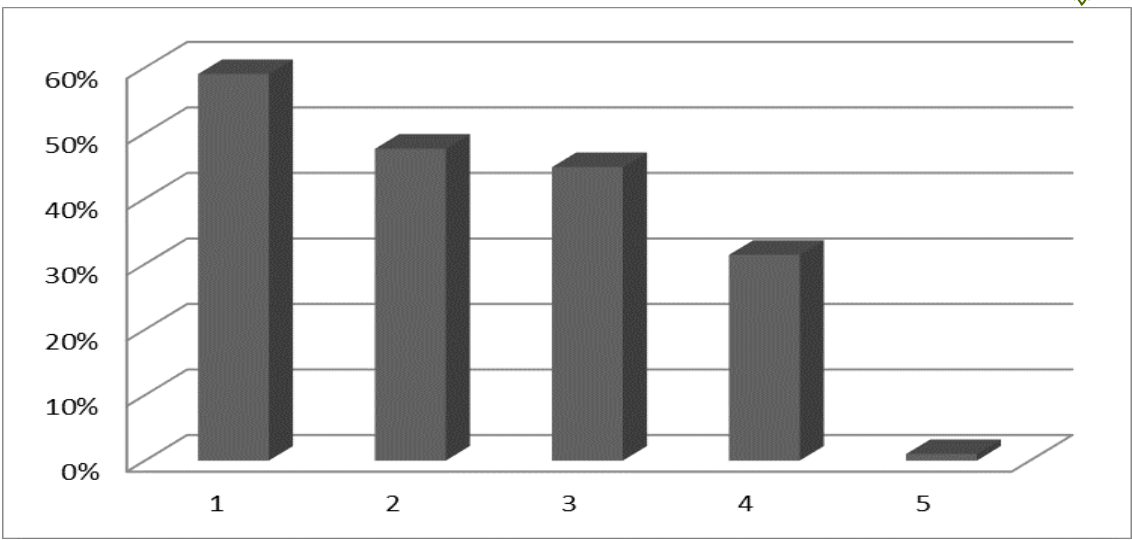

Рис. 5. Що, на Вашу думку, може перешкоджати людям займатися волонтерською діяльністю?

Умовні позначення: 1 - байдужість до проблем інших людей; 2 - недостатність інформації про акції, події та волонтерські організації, які їх влаштовують; 3 - нестача часу; 4 - відсутність матеріальної винагороди; 5 - інше

Однак найважливіший мотиваційний чинник - бажання допомогти нужденним. 79\% учасників опитування вважають, що саме воно спонукає людей до участі у волонтерському русі. Ще одним значимим фактором, який $47,6 \%$ опитаних визначили як такий, що може стимулювати населення до волонтерства, $\epsilon$ надбання корисних соціальних і практичних навичок. Третьою за актуальністю визнано можливість спеціалізованого навчання, залучення до міжнародних програм обміну. Майже однакову цінність мають такі мотиваційні фактори, як матеріальні стимули, пільги при вступі до ЗВО та пільги при прийомі на роботу (рис. 6).

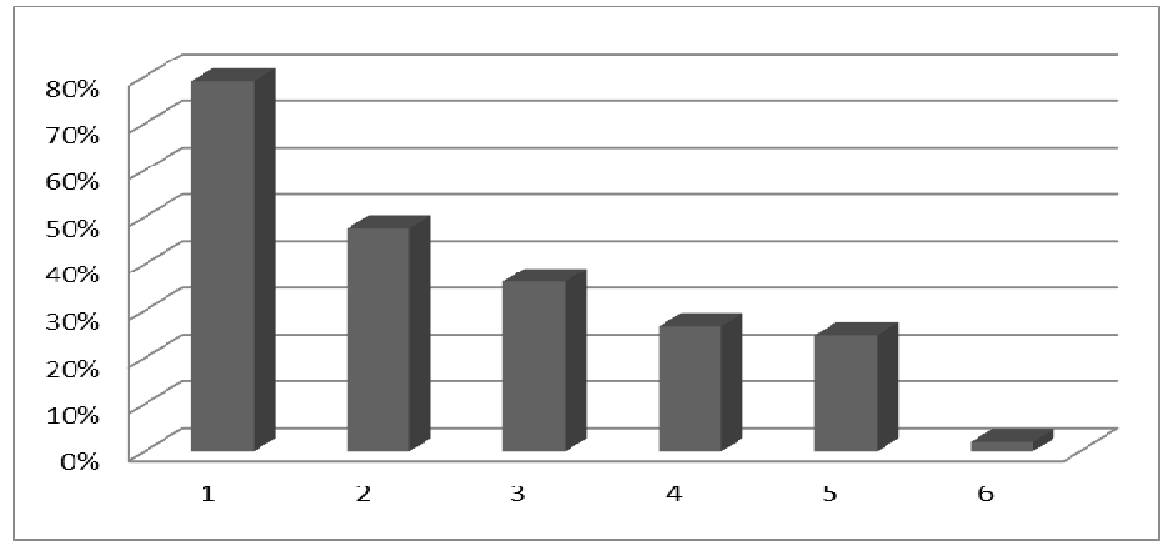

Рис. 6. Що, на Вашу думку, може спонукати людей займатися волонтерською діяльністю?

Умовні позначення: 1 - бажання допомогти нужденним; 2 - надбання корисних соціальних і практичних навичок; 3 - можливість спеціалізованого навчання, міжнародні програми обміну; 4 - пільги при вступі до ЗВО та при прийомі на роботу; 5 - матеріальні стимули; 6 - інше 
Важливим моментом дослідження $€$ визначення обізнаності населення щодо сфер, за якими сьогодні здійснюється волонтерська діяльність в Україні. Половина опитаних нами громадян достатньо поінформовані й знають, за якими напрямками працюють волонтери. Багато людей $(43,8 \%)$ погано орієнтуються у сферах благодійництва i 6 осіб з усіх опитаних зовсім не орієнтуються, за якими напрямами працюють добровольці.

Також вважаємо за доцільне ідентифікувати думку респондентів щодо найбільш актуальних на сьогодні напрямів волонтерства (перелік сформовано на основі [1; 2]) в Україні. Беззаперечну першість надано таким напрямам волонтерської діяльності, як допомога українським військовим, постраждалим внаслідок бойових дій - 80\% та підтримка знедолених категорій населення - 82,9\% опитаних. Зважаючи на соціально-економічне становище та політичну ситуацію в нашій державі, це досить очікувані результати опитування, які ще раз підтверджують необхідність підтримки соціально вразливих верств населення в умовах економічної нестабільності та важливість своєчасної допомоги армії. 57,1\% респондентів вважають нагальними турботу про довкілля та охорону навколишнього середовища. Окрім допомоги людям, для учасників опитування актуальною виявилася необхідність турботи про тварин - 48,4\%. 19 осіб зазначили важливість поширення гуманістичних та альтруїстичних ідей та настроїв у суспільстві. Найнижча значущість виявилася у таких напрямів, як збір коштів на суспільно-корисні цілі, виконання ремонтних робіт та організація дозвілля (рис. 7).

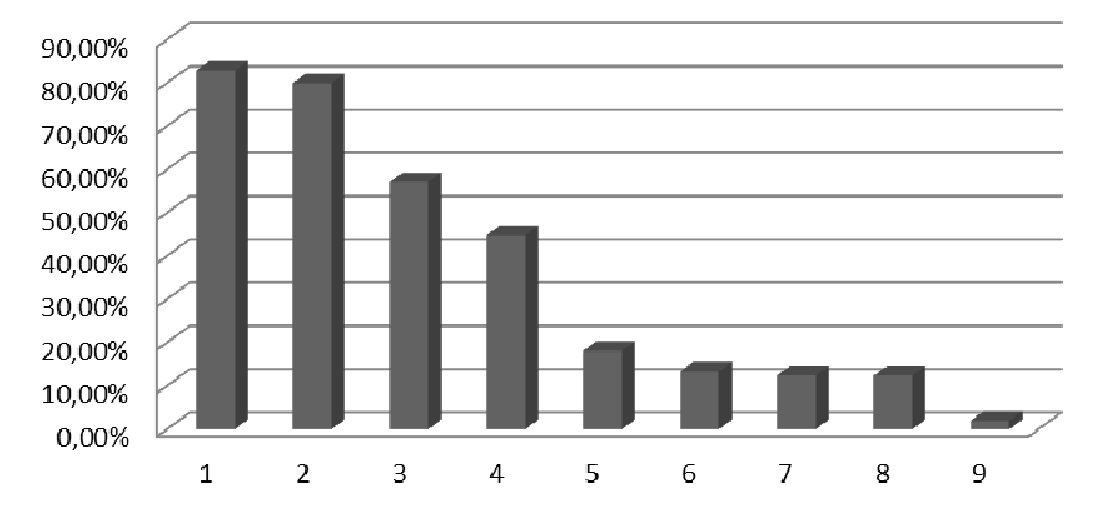

Рис. 7. Які напрямки волонтерства, на Вашу думку, є сьогодні найбільш актуальними?

Умовні позначення: 1 - підтримка знедолених категорій населення (сироти, пенсіонери, малозабезпечені); 2 - допомога українським військовим /постраждалим внаслідок бойових дій; 3 - турбота про довкілля, охорона навколишнього середовища; 4 - допомога бездомним тваринам; 5 - поширення гуманістичних та альтруїстичних ідей та настроїв в суспільстві; 6 - організація дозвілля; 7 - збір коштів на суспільно-корисні цілі; 8 - виконання ремонтних робіт; 9 - інше 
Респонденти також визначили основні види волонтерських робіт, якими займаються зараз або до яких могли б долучитися. Найбільше респондентів $(51,4 \%)$ готові надавати допомогу потребуючим категоріям населення, адже, враховуючи напружений політичний та економічний стан в нашій країні, ця сфера соціальної політики сьогодні $€$ вкрай вразливою й очікує підтримки від кожної небайдужої людини. Другою за популярністю (43,8\% опитаних) $€$ турбота про екологію, що сьогодні популярно в усьому світі. Наступними за прихильністю респондентів напрямами є підтримка української армії /постраждалих внаслідок бойових дій - готові долучитися 36 осіб та допомога бездомним тваринам - можливість співучасті задекларували 35 учасників опитування. Багато респондентів вважають за доцільне долучатися до благоустрою й озеленення вулиць населених пунктів та організації дозвілля. Найменш привабливими для себе респонденти визначили такі види волонтерської діяльності, як поширення гуманістичних та альтруїстичних ідей та настроїв в суспільстві та збір коштів на суспільно-корисні цілі (рис. 8).

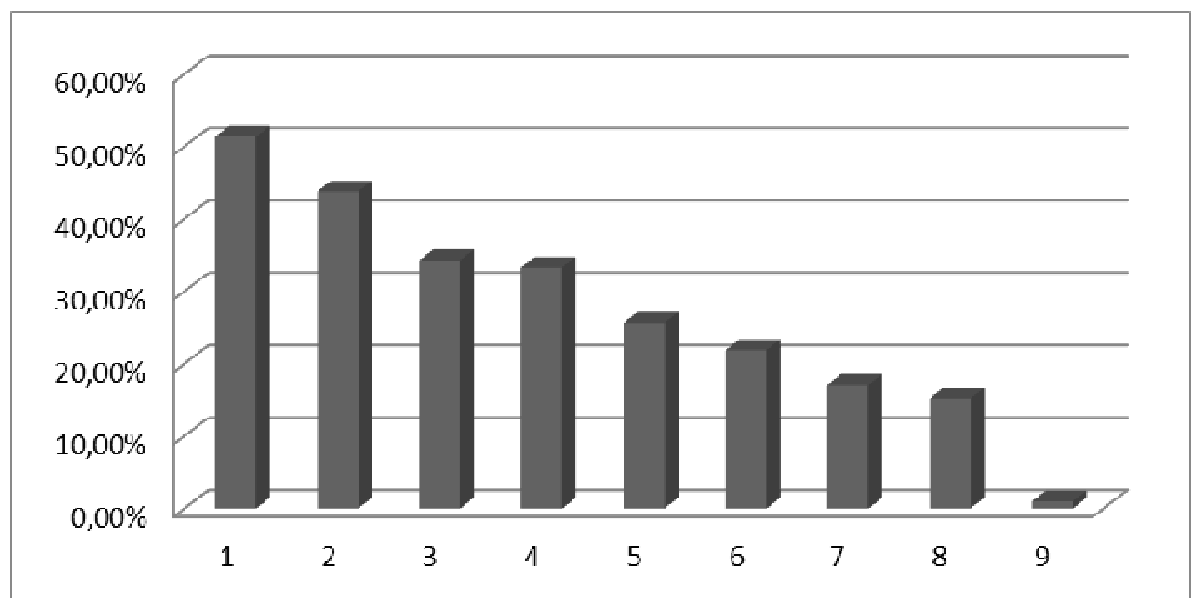

Рис. 8. До яких видів волонтерства Ви могли б долучитися або займаєтесь ними зараз?

Умовні позначення: 1 - допомога потребуючим категоріям населення; 2 - турбота про екологію; 3 - підтримка української армії/постраждалих внаслідок бойових дій; 4 - допомога бездомним тваринам; 5 - благоустрій/озеленення вулиць; 6 - організація дозвілля; 7 - поширення гуманістичних та альтруїстичних ідей та настроїв в суспільстві; 8 - збір коштів; 9 - інше

При цьому значна частка опитаних (69 осіб) вважає, що необхідність волонтера володіти спеціалізованою освітою залежить від виду його діяльності. На думку $30,5 \%$ респондентів, спеціалізована освіта добровольцям взагалі не потрібна. 
Оперативно реагуючи на нагальні потреби суспільства, волонтерство $€$ важливою складовою розвитку кожної соціально орієнтованої держави. Щоб волонтерський рух набув системного а не ситуаційного характеру, праця добровольців не може постійно грунтуватися тільки на їхніх ціннісних орієнтаціях і внутрішніх мотивах, націлених на безкорисну допомогу іншим. Для підтримки й постійного ефективного функціонування даного виду суспільнокорисної діяльності необхідно сформувати дієву систему стимулювання населення до волонтерства.

1. Про волонтерську діяльність : Закон України від 19.04.2011 № 3236-VI. URL: https://zakon.rada.gov.ua/laws/show/3236-17 (дата звернення: 10.11.2020). 2. Волонтерський рух: світовий досвід та українські громадянські практики : аналітична доповідь.

URL: http://www.niss.gov.ua/content/articles/files/volonter+697e4.pdf. (дата звернення: 10.11.2020).

\title{
REFERENCES:
}

1. Pro volontersku diialnist : Zakon Ukrainy vid 19.04.2011 № 3236-VI. URL: https://zakon.rada.gov.ua/laws/show/3236-17 (data zvernennia: 10.11.2020). 2. Volonterskyi rukh: svitovyi dosvid ta ukrainski hromadianski praktyky : analitychna dopovid. URL: http://www.niss.gov.ua/content/articles/files/volonter+697e4.pdf. (data zvernennia: 10.11.2020).

\author{
Mazur N. O. [1; ORCID ID: 0000-0001-8673-5873], \\ Candidate of Economics (Ph.D.), Associate Professor \\ Tseliukh Ya. O. [1; ORCID ID: 0000-0002-5541-1953]
} Senior Student ${ }^{1}$ National University of Water and Environmental Engineering, Rivne TRENDS AND MOTIVES OF VOLUNTEERING IN UKRAINE

The main resource for the implementation of many social programs in any country is the population. This determines the relevance of the study of opportunities to involve citizens in this type of socially useful activities. However, there are almost no systematic studies of the real awareness of different categories of the population about peculiarities of volunteering and about the citizens' motives to this type of charity. Therefore, the task of monitoring the mood of society regarding the peculiarities of the development of volunteering in our country, including the main factors that motivate people to charity, appears.

The main trends in the attitude of the population of Ukraine to volunteering are identified based on our own sociological research. The relevance of different types of volunteering for modern Ukrainian society 
and the commitment of the survey participants to each of them is determined. The motives for involving citizens in volunteer work are identified.

We interviewed 105 respondents of different ages, occupations, with different income levels and from different regions of Ukraine. $80 \%$ of respondents declared a positive attitude to volunteering. Today, the most relevant citizens of our country consider such areas as assistance to the Ukrainian military / victims of hostilities and support for disadvantaged groups. Equally important is caring for the environment and caring for animals. Respondents consider the desire to help the needy to be the most important motivating factor for charity. Acquisition of useful social and practical skills, the possibility of specialized training and involvement in international exchange programs also encourage people to volunteer. According to the results of the sociological research, the most important deterrents are indifference to the problems of others and lack of information about actions, events and volunteer organizations that implement them.

In order for the volunteer movement to become systemic rather than situational, the work of volunteers cannot be constantly based solely on their values and internal motives aimed at uselessly helping others. To support and continue the effective functioning of this type of socially useful activity, it is necessary to form an effective system of stimulating the population to volunteer.

Keywords: volunteering; volunteer activity; motivation for volunteering; areas of volunteering; sociological research.

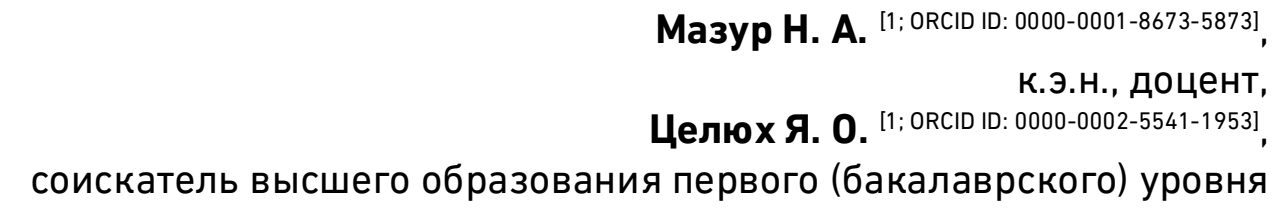

${ }^{1}$ Национальный университет водного хозяйства и природопользования, г. Ровно

\section{ТЕНДЕНЦИИ И МОТИВЫ РАЗВИТИЯ ВОЛОНТЕРСТВА В УКРАИНЕ}

На основе социологического исследования выявлены основные тенденции отношения населения Украины к волонтерской работе. Определена актуальность различных видов волонтерской деятельности для современного украинского общества. Исследован уровень приверженности участников опроса к каждому из направлений благотворительности. Идентифицированы мотивы и сдерживающие факторы привлечения граждан к волонтерской деятельности.

Ключевые слова: волонтерство; волонтерская деятельность; мотивирование волонтерства; сферы волонтерской деятельности; социологическое исследование. 